\author{
Antonio-Luis Martínez-Pujalte \\ Miguel Hernández University of Elche, Spain \\ ORCID: 0000-0001-5396-1065 \\ almart@umh.es
}

\title{
Models of Disability and Their Influence on Judicial Decisions: A Preliminary Approach from the Perspective of the Spanish Case Law
}

Modele niepełnosprawności i ich wpływ na decyzje sądowe. Wstępne podejście z perspektywy hiszpańskiego orzecznictwa

\section{SUMMARY}

The purpose of this article is to show the influence on judicial decisions of the approach to disability embedded in the person's mentality. A brief introduction to the different paradigms of disability is previously provided, distinguishing mainly between the medical and the social model, and noting that the latter has been incorporated by the Convention on the Rights of Persons with Disabilities. The analysis of two recent decisions of the Spanish Supreme Court illustrates the influence of the different models of disability on legal judgements. Finally, some conclusions from this analysis are suggested, which can mark a path for future research.

Keywords: disability; the Convention on the Rights of Persons with Disabilities; judicial interpretation of the law

\section{INTRODUCTION: MEDICAL VS SOCIAL MODEL OF DISABILITY}

According to A. Palacios, among other authors, three different models of treatment of disability by society and Law can be identified throughout history ${ }^{1}$. The most ancient one, that she calls "disregarding model", is based on the assumption

1 A. Palacios, The social model in the International Convention on the Rights of Persons with Disabilities, "The Age of Human Rights Journal” 2015, Vol. 4, pp. 91-110. A deeper analysis in: eadem, El modelo social de discapacidad: orígenes, caracterización y plasmación en la Convención Internacional sobre los Derechos de las Personas con Discapacidad, Madrid 2008. See also A. Martínez-Pujalte, Derechos fundamentales y discapacidad, Madrid 2015. 
that persons with disabilities do not provide anything useful to society and their life is not worth living, and therefore they are "disregarded", and either physically eliminated or excluded from society and placed in a space of marginalization. In the second model, the person with a disability is seen as a sick person, who has to be cared for and is the object of a public policy aimed to his or her healing and rehabilitation; and is deemed as capable of lending a useful contribution to society only as long as he or she is rehabilitated. There is, however, a substantial continuity between this rehabilitation model - also called by other authors "medical model" and the previous one, because the person will be excluded from society if his or her recovery is not achieved, and, above all, when it appears as impossible. The basic feature of this medical model is, moreover, that it locates disability within the individual: it is "exclusively a problem of the person, produced by disease, accident or a health condition that requires medical care provided by professionals in the form of individual treatments"2. And, if the person is excluded from society, exclusion is regarded as an individual problem and the reasons for exclusion are seen in the impairment. The third model means, on the contrary, a radical change of perspective, because it stresses equal dignity of all human beings independently from their capacities, requiring thus full integration and participation of everyone in society, also of persons with disabilities. The focal point moves now from the conditions of the person that entail an impairment towards the conditions of society that impede his or her full participation of society because he or she faces the barriers of a social environment that has not been designed considering his or her needs. Therefore, this model has been called "social model"; or, as S. French and J. Swain have observed, the "barriers approach":

[...] disability is viewed not in terms of the individual's impairment, but in terms of environmental, structural and attitudinal barriers that impinge upon the lives of disabled people and which have the potential to impede their inclusion and progress in many areas of life, including employment, education and leisure, unless they are minimized or removed ${ }^{3}$.

On 13 December 2006, the General Assembly of the United Nations approved the Convention on the Rights of Persons with Disabilities (hereinafter: the Convention), which, according to its Article 45, entered into force on 3 May 2008 ("on the thirtieth day after the deposit of the twentieth instrument of ratification or accession"), and which up to this moment has been ratified by 181 countries. As many authors have already pointed out, the Convention means a deep change of paradigm in the approach

A. Palacios, The social model..., p. 93.

3 S. French, J. Swain, Changing relationships for promoting health, [in:] Tidy's Physiotherapy, ed. S. Porter, Edinburgh 2013, pp. 183-205. 
of society and Law to the phenomenon of disability ${ }^{4}$. While, until recently, the medical model of disability has been the dominant paradigm - and it is still reflected in many national laws ${ }^{5}$ - the Convention adopts the social model of disability from its Preamble, which asserts that "disability results from the interaction between persons with impairments and attitudinal and environmental barriers that hinders their full and effective participation in society on an equal basis with others". In connection with this explanation of disability, Article 1 of the Convention defines persons with disabilities as "those who have long-term physical, mental, intellectual or sensory impairments which in interaction with various barriers may hinder their full and effective participation in society on an equal basis with others". As can be seen, the center of the concept of disability provided by the Convention is the existence of barriers to social participation; of course, those barriers have to be related to an impairment of the person - because, otherwise, we would not talk about disability, but about some other form of discrimination - but what causes disability is not the impairment itself: in fact, there can be an impairment which is not associated to barriers, like for example myopia, and in such a case there is no disability. What determines the appearance of disability is that there are barriers placed by society, which hinder social participation.

An important consequence of social model of disability is the emphasis placed on non-discrimination on the basis of disability, which is a basic principle of the Convention, to which Article 5 is devoted; moreover, most articles reflect also this principle, because they recognize the different human rights to persons with disabilities "on an equal basis with others", a clause which is very often repeated throughout the Convention. As equal participation and enjoyment of their rights by persons with disabilities is hindered by environmental barriers, the main duty of public powers is to remove those barriers. As A. Palacios writes,

[...] the obstacles faced by persons with disabilities when exercising their rights are the result of a society exclusively thought for an average standard person (the model of which is normally provided by a non-disabled man). In order to remove these barriers, the Convention puts forward various strategies, which require a wide and inclusive look at human diversity ${ }^{6}$.

4 See the contributions by Palacios quoted in footnote 1 . See also T. Degener, A human rights model of disability, [in:] Handbook of Disability Law and Human Rights, eds. P. Blanck, E. Flynn, London 2016, pp. 31-49.

5 See, e.g., the definition of disability contained in section 6 of the English Equality Act, 2010: "A person (P) has a disability if (a) P has a physical or mental impairment, and (b) the impairment has a substantial and long-term adverse effect on P's ability to carry out normal day-to-day activities". As can be seen, this definition focuses only on the impairment of the person and its adverse effects, making no reference to the barriers posed by society. Therefore, it is a definition not consistent with the Convention, which adopts a quite different approach, as is explained in the text.

${ }^{6}$ A. Palacios, The social model..., p. 102. 
The Convention aims at universal accessibility, which is also a basic principle, to which Article 9 is devoted. If universal accessibility is not possible, the Convention provides for reasonable accommodations. And, in connection with the different rights recognized, various measures are established to facilitate access to rights, e.g. support in exercising legal capacity (Article 12), procedural accommodations for access to justice (Article 13), community support services to prevent segregation from the community (Article 19), individualized support measures in the field of education (Article 24), assistance in employment (Article 27), assistance in voting (Article 29), etc.

The purpose of the present study is to show the influence on judicial decisions of the approach to disability embedded in the person's mentality. As has been shown, the Convention is inspired by the social model of disability. But that does not mean that this paradigm has been already incorporated into the mentality of the people, not even those who serve as judges. And their approach to disability influences their decisions. I will show this by selecting two recent important judgements of the Spanish Supreme Court related to disability.

\section{THE MEDICAL MODEL: JUDGEMENT OF THE SPANISH SUPREME COURT OF 17 MARCH 2016}

Until its recent reform by Organic Law 2/2018 of 5 December, which recognized right to vote to all persons with disabilities, Spanish Electoral Law contained a provision (Article 3.1.b) authorizing judges to deprive persons with disabilities who had been declared legally incapable of their right to vote. This is the question examined by the Spanish Supreme Court in the judgement of 17 March 2016. A young woman called Rosalia had been declared legally incapable, and guardianship had been entrusted to her parents. In application of Article 3.1.b of the Spanish Electoral Law, she was also deprived from the right to vote. The parents appealed the judgement before the Supreme Court only in relation to this aspect. The Supreme Court dismissed the appeal and confirmed the initial judgement.

That the reasoning of the Spanish Supreme Court is based on the medical model of disability is clearly shown by two main facts. On the one hand, the main argument used by the Supreme Court is the best interest of the person. It explicitly states that the measure adopted must be the most beneficial for the interest of the person, and afterwards it confirms - without providing a justification of this conclusion - that in this case the most beneficial measure is the deprivation of her right to vote, although the Court recognizes that she wished to participate in elections. As can be seen, the "best interests" paradigm, as it has been called by the UN Committee on the Rights of Persons with Disabilities, entails substituting the will and preferences on the person by what is believed to be in her objective "best interests", and it is 
based on the assumption that the person cannot make a right decision because of her impairments, being thus a remnant of the medical model ${ }^{7}$. On the other hand, the Court insists indeed on the impairments of the person, arguing that they impede her to exercise her right to vote. In this sense, the judgement explains that her cognitive competences are equal to a child between 6 and 8 years of age, that she has an almost total ignorance of the value of money and of basic legal concepts, that she shows a lack of basic political knowledge (ignorance on political parties or on the content of elections), and that she lacks capacity to make elementary decisions; all these reasons confirm, in opinion of the Court, that she lacks the basic skills which are necessary to exercise the right to vote.

An appropriate assessment of this decision of the Spanish Supreme Court requires taking into account that, in Spanish Law, international treaties which have been validly concluded and officially published are directly applicable, and their development or implementation by internal legal regulations is not required. In this sense, Article 96.1 of the Spanish Constitution states that "validly concluded international treaties, once officially published in Spain, shall be part of the internal legal system", and the Act 25/2014 of 27 November on International Treaties, confirms explicitly that they are directly applicable, "unless it is clear from their text that such application is conditional on the approval of relevant laws or regulatory provisions" (Article 30), and that they prevail over any other internal rule in case of conflict (Article 31).

Article 29 of the Convention on the Rights of Persons with Disabilities requires State Parties "to ensure that persons with disabilities can effectively and fully participate in political and public life on an equal basis with others, directly or through freely chosen representatives, including the right and opportunity for persons with disabilities to vote". This rule contains a direct and explicit recognition of right to vote to persons with disabilities, with no limitation, and was, therefore, clearly contradictory with Article 3.1.b of the Spanish Electoral Law. Therefore, the Supreme Court, according to Article 31 of the Act on International Treaties, should have decided the prevalence of Article 29 of the Convention and rejected the application of Article 3.1.b of the Electoral Law. Why wasn't this the decision of the Spanish Supreme Court? Because its decision is based on a preconception of disability, which is implicitly shown by its reasoning. And I call it a preconception because it is not grounded on legal norms or on the facts of the case. According to such preconception: 1) persons with disabilities are not entirely free; therefore, the Court invokes as an argument of its decision "the protection of the general interest

7 On the "best interests" paradigm, see Committee on the Rights of Persons with Disabilities, General Comment No. 1, Article 12: Equal recognition before the Law, 19 May 2014, specially No. 21 and 27 (retrieved from: https://documents-dds-ny.un.org/doc/UNDOC/GEN/G14/031/20/PDF/ G1403120.pdf?OpenElement, access: 24.05.2020). 
in a free participation in elections"; 2) persons with disabilities should be protected against their own preferences, and should be helped and cared for even if they do not want such help or care (in a few words, we can talk about a paternalist preconception of disability, which is also characteristic of the medical model); therefore, although in this case the person wishes to participate in elections, the Court decides that denial of that participation is better protection of her interests; 3 ) the exclusion of society - in this case, of political participation - of the person with a disability is only a natural consequence of her impairments. This preconception leads the Court to take the decision of depriving the person of her right to vote ${ }^{8}$.

In my opinion, the judgement of Spanish Supreme Court of 17 March 2016 clearly shows the influence of the preconception of disability - in this case, a preconception closely linked to a medical model of disability - on judicial decisions. In the next section, I will contrast it with another more recent decision of the Court.

\section{THE SOCIAL MODEL: JUDGEMENT OF THE SPANISH SUPREME COURT OF 21 JUNE 2019}

The judgement of the Spanish Supreme Court of 21 June 2019 deals with the right of persons with disabilities to inclusive education. In the case, the parents of a child of 4 years of age with a developmental disability chose for him a public ordinary school, which I will call School A, but the educational authorities decided his schooling in another public school, School B (which was also an ordinary school, not a special school for children with disabilities). The parents based their choice of School A on two reasons. On the one hand, School A concentrated all the classes in the morning, from 9.00 am to $2.00 \mathrm{pm}$, while School B had a split working day, the schedule being from 9.30 to 12.30 and from 15.00 to 17.00; and, in the opinion of the parents, the first schedule is more appropriate for their child, because in the afternoon he has to attend individual therapy sessions, and because it concentrates classes in the time of the day where he is more awake and receptive. On the other

8 It should be pointed out that this judgement of the Supreme Court was confirmed by the Spanish Constitutional Court, which denied the constitutional complaint filed by the parents of Rosalia (decision of 28 November 2016). Apart from a weak and inconsistent argumentation attempting to show the compatibility between Article 3.1.b of the Spanish Electoral Law and Article 29 of the Convention, the decision of the Constitutional Court does not add new arguments to those used by the Supreme Court, but insists mainly on the lack of freedom of Rosalia - therefore, she is not capable to exercise freely her right to vote - and the fact that she can be easily influenced by other persons. A further examination of these judgements and the problems related can be seen in: P. Cuenca Gomez, El derecho al voto de las personas con discapacidad intelectual y psicosocial. La adaptación de la legislación electoral española a la Convención Internacional de los Derechos de las Personas con Discapacidad, "Derechos y Libertades" 2018, No. 38, pp. 171-202. 
hand, the mother is a teacher at School A. However, the authorities decided that he should attend School B, because School B has an educational assistant, which lacks in School A, who would be in charge of the personal attention to the child. The parents challenged this decision before the Regional Court. After the dismissal of their petition, they appealed to the Supreme Court.

Although the Supreme Court's argumentation is not quite systematic, two main reasons can be discovered in support of its decision. Firstly, the Supreme Court recognizes that the right to inclusive education is not formally at issue, because both schools, the school preferred by the parents and the school decided by the Public Administration, are inclusive schools, where children with and without disabilities interact. But the right to inclusive education is not satisfied merely by the fact that children with disabilities and children without disabilities share the same school; on the contrary, it requires to provide education in the environment where the children can reach their maximum personal development, taking into account the particular needs and circumstances of each child, in order to guarantee that each child effectively benefits from education and achieves progresses on an equal basis with others. Secondly, although, according to the Spanish Education Act (Article 84), the right of the parents to choose a specific school for their children is subordinated to the availability of school posts, in this case to attend the preference of the parents can be seen as a reasonable accommodation, that has to be provided to ensure to persons with disabilities the enjoyment or exercise of their rights on an equal basis with others (Article 2 of the Convention), unless it imposes a disproportionate or undue burden. The arguments provided by plaintiffs, in this case, show that the most appropriate environment for the child is School A, the one preferred by the parents; while it has not been proved that placing the child in School A imposes a disproportionate or undue burden. Therefore, the Supreme Court upholds the appeal and annuls the decision of placing the child in School B.

Can we say that this judgement is based on a different preconception of disability than the one presented in the previous section of this article? I think that there are strong reasons to give indeed an affirmative answer to this question. In particular, there are three aspects of the reasoning of the Court that deserve to be outlined and that mark a heavy contrast with the judgement examined in the previous section. Firstly, as has been shown the whole reasoning of the Court is founded on a discourse of human rights. In fact, the decision of the Court is solely based on the rights of persons with disabilities (in this case, of the plaintiffs' son): right to inclusive education and right to equality (which includes the right to reasonable accommodations). No other argument is taken into account. Secondly, it is interesting to notice that the Court takes for granted, and therefore does not consider necessary to offer an explicit justification, that the right to education entails the right to "inclusive" education, provided thus in ordinary schools shared by children with disabilities and children without disabilities, implicitly rejecting in this way 
any kind of segregation or exclusion of persons with disabilities. But probably the most remarkable feature of the reasoning of the Court, in this case, is that, in contrast with the previous judgement, it makes no link between the impairment of the child and any disadvantage that he has to suffer or tolerate. It would have been easy to argue, for example, that, because he has an impairment, he needs the help of an assistant, and therefore his freedom of choice cannot be respected (in this case, freedom of choice is exercised by his parents on his behalf, as he is a minor of only 4 years of age). But such an argument does not appear in the judgement. In fact, the only reference to the impairment that can be read in the judgement is made by the parents, to justify that the most appropriate schedule for their child is the one offered by School A.

The analysis that has just been carried out proves consistently, in my opinion, that the judgement of Spanish Supreme Court of 21 June 2019 reflects an approach to disability essentially different from that shown in the judgement of 17 March 2016. In other words, while the latter is based on the medical model of disability, the decision of 2019 clearly assumes the social model. It could be objected, however, that what the Supreme Court does in this judgement is merely to apply the provisions of the Convention - in particular Article 24.2.d, that requires States Parties to provide education to persons with disabilities "in environments that maximize academic and social development", and Article 5.3, which orders the implementation of reasonable accommodations to protect equality - and, therefore, there is no need to seek an explanation of its decision in a supposed preconception of disability. However, this objection can be easily refuted. It is true, of course, that the Convention plays a key role in the judgement as the main normative justification of the decision. This is completely reasonable, because, as has already been explained, the Convention is in Spain a binding and directly applicable legal source, and is also, according to Article 10.2 of the Spanish Constitution ${ }^{9}$, an interpretative parameter of the internal norms on fundamental rights recognized by the Constitution, as in this case right to education, recognized by Article 27. But it is also true that the Convention does not offer an explicit answer to the problem examined in the judgement. Therefore, the decision that has been adopted and, above all, the reasoning of the Court, show that, beyond the strict application of the provisions of the Convention, what the Tribunal has assumed is the paradigm of disability that underlies it. We find a reasoning and a decision drawn up from the premises of the social model, which the Court has made its own and that, therefore, becomes the preconception from which the Court reads legal norms.

9 Article 10.2 of the Spanish Constitution: "Provisions relating to the fundamental rights and liberties recognized by the Constitution shall be interpreted in conformity with the Universal Declaration of Human Rights and international treaties and agreements thereon ratified by Spain". 


\section{CONCLUDING REMARKS}

As is shown by the title of this article, the precedent study of two selected judgements of the Spanish Supreme Court related to disability can only be seen as a preliminary approach to the question proposed: the influence of preconceptions of disability on judicial decisions. A wider research should be conducted, examining more judgements and comparing decisions from different national courts. Nevertheless, this first analysis authorizes to draw some provisory conclusions, which can show a path for future research.

On the one hand, although the Convention on the Rights of Persons with Disabilities entered into force more than 10 years ago, it seems that the social model of disability that informs it has not yet permeated the common mentality, not even that of legal operators, what highlights the importance of awareness-raising about a correct understanding of disability and about the correct approach towards persons with disabilities. I use the word "correct", because, although it might seem obvious, it is perhaps convenient to point out explicitly that the different perspectives on disability mentioned in the first section of this article are not neutral theoretical approaches among which one can choose; on the contrary, the disregarding model and the medical model have serious ethical difficulties, while the social model is the only one fully consistent with respect of human dignity. Indeed, the principle of human dignity underlines that the person deserves a respect which is not linked to his or her particular conditions or features; it is, properly said, an unconditional respect. The main specification of this respect is the duty to respect and protect the basic person's goods, what we call human rights. But this requirement of unconditional respect to the person has also other consequences. Firstly, as all persons deserve an equal respect, all have an equal entitlement to take an active role in the community. Secondly, the proclamation of human dignity as the basis of legal and political order, contained in most modern constitutions ${ }^{10}$, entails that the point of view from which political community and Law have to see every person is even his or her condition of person, which is his or her most prominent feature, while other characteristics or attributes are merely secondary. Finally, respect of human dignity implies for the political community the duty to take all measures required to facilitate full participation in society and enjoyment of his or her rights by every person when he or she faces obstacles that impede it. In relation to disability, these principles require to ensure full participation of persons with disabilities in society, protection of their human rights and of their equality with any other persons, and the implementation of the measures which might be needed to protect these demands removing social barriers that hinder their satisfaction. These are in fact the

${ }^{10}$ See, e.g., Article 1 of the German Constitution, Article 10.1 of the Spanish Constitution or Article 30 of the Constitution of the Republic of Poland. 
main premises of social model, that are, as can be seen, a translation of the basic requirements of human dignity.

Nevertheless, although the social model is based on recognition of human dignity, it has to be acknowledged that it constitutes a completely new paradigm, which in some aspects can be described without exaggeration as revolutionary, and which requires a change of mentality and even a revision of traditional legal institutions and concepts that have lasted for centuries ${ }^{11}$. This circumstance highlights the importance of awareness-raising and of appropriate training of legal operators. In fact, the Convention devotes an article to this issue, Article 8, which requires the adoption of measures by State Parties to foster respect for the rights and dignity of persons with disabilities, to combat stereotypes, and to promote awareness of the capabilities and contributions of persons with disabilities; and Article 13.2 adds that "States Parties shall promote appropriate training for those working in the field of administration of justice". A recent report of the Office of the United Nations High Commissioner for Human Rights has insisted on the significance of awareness-raising to achieve the objectives of the Convention, emphasizing that "awareness-raising plays a key role in promoting respect for human rights as it targets the underlying attitudes, values and beliefs that are at the root of human rights violations, including discriminatory laws, policies, discourse and conduct"12. It is interesting to point out that, according to this report, "the charity and medical models are the most prevalent in law, policy and practice" 13 , what has been confirmed by the analysis of the Spanish Supreme Court's judgement of 17 March 2016 provided in section 2 of the present article. Moreover, the report mentions as one of the most common stereotypes against persons with disabilities the assumption that "persons with disabilities need protection", what "leads to infantilization, substi-

${ }^{11}$ For example, the concepts and institutions related with legal capacity and guardianship, see on this question: A. Martínez-Pujalte, Legal Capacity and Supported Decision-Making: Lessons from Some Recent Legal Reforms, "Laws" 2019, Vol. 8(1), DOI: https://doi.org/10.3390/laws8010004, p. 4; A. Arstein-Kerslake, Restoring Voice to People with Cognitive Disabilities: Realizing the Right to Equal Recognition before the Law, Cambridge 2017.

12 Office of the United Nations High Commissioner for Human Rights, Awareness-raising under Article 8 of the Convention on the Rights of Persons with Disabilities (A/HRC/43/27), 17 December 2019, No. 5, www.ohchr.org/Documents/Issues/Disability/Article8/A_HRC_43_27_AdvanceEditedVersion.docx [access: 20.01.2020].

${ }^{13}$ Ibidem, No. 12. Following Palacios (The social model...), the present article does not distinguish between the charity model and the medical model but considers them as one. In fact, the report of the UN High Commissioner for Human Rights defines the charity model in the following terms: "The charity model considers persons with disabilities as passive objects of kind (charitable) acts or welfare recipients only, rather than as empowered individuals with equal rights. Under this model, disability is an individual's problem and persons with disabilities are not considered capable of providing for themselves on account of their impairments; rather, they are considered as a burden on society, which bestows its benevolence on them". All those are in our conception features of the medical model, as explained in section 1 . 
tution of the person in decision-making and denial of autonomy" and has as legal consequence that persons with disabilities are denied "legal agency to make their own decisions". As was examined in section 2, this stereotype is indeed the main justification of the decision of the Supreme Court on the right to vote, associated to the stereotype, also commented by the report, that "persons with disabilities are incapable"14. To combat these stereotypes and to instil a new look towards disability seems, therefore, crucial to achieve effective implementation of the Convention.

On the other hand, the second conclusion that can be drawn from the preliminary study presented in this article is rather of a legal-philosophical nature, and to examine it deeply exceeds the purpose of these pages. But it should be at least pointed out that the analysis of the influence of preconceptions of disability on judicial decisions that has been carried out shows in fact only a specific example of a more general phenomenon: the influence of values on judicial decisions. This issue has received particular attention from North American scholars ${ }^{15}$, while a study of the influence of values on judicial decisions in European statutory legal systems remains to be done $^{16}$. Of course, what seems evident is that old principles of legal positivism have to be discarded, because they do not provide a satisfactory explanation of real legal experience. In this context, two theses of legal positivism deserve especially to be mentioned: its theory of legal interpretation, according to which legal interpretation is a merely mechanical and rational enterprise, strictly submitted to certain logical rules, and what N. Bobbio calls methodological positivism, according to which Law is an objective and neutral science, which has to be thus completely separated from ideological and moral values, that are always subjective ${ }^{17}$. On the contrary, real legal experience shows the difficulty of selecting and determining the legal norm that is applicable to each case, in a complex legal system with a plurality of legal sources among which there is not always a precise hierarchy, as well as the difficulty of subsuming varied human behaviors in the concepts used by legal norms, which are very often abstract and uncertain. These factors, among others, compel to admit that legal interpretation entails a wide margin of discretion and requires from the interpret different valuations, that are in many cases subjective

${ }^{14}$ Ibidem, No. 19 and 20.

15 According to D.J. Danielski (Values as variables in Judicial Decision-Making: Notes toward a Theory, "Vanderbilt Law Review" 1965, Vol. 19, pp. 721-740), the tradition of a scientific study of values in judicial decisions begins with the studies of H. Pritchett in the 1940s, especially his book The Roosevelt Court (New York 1948). Among the most recent contributions, see R. Cahill-O'Callaghan, The influence of personal values on legal judgments, "Journal of Law and Society" 2013, Vol. 40(4), DOI: https://doi.org/10.1111/j.1467-6478.2013.00642.x, pp. 596-623.

${ }^{16}$ In Poland, W. Dziedziak (Axiological Basis for the Application of Law - A Perspective of the Equitable Law, „Studia Iuridica Lublinensia” 2015, Vol. 24(2), DOI: https://doi.org/10.17951/ sil.2015.24.2.49, pp. 41-71) has provided some theoretical basis for that study, but what lacks is a comprehensive empirical research of the real influence on values on legal judgements.

${ }^{17}$ See N. Bobbio, Il positivismo giuridico, Torino 1979. 
and are, therefore, unavoidably led by his or her personal ethical and ideological conceptions ${ }^{18}$. To clarify to which extent judicial decisions are determined by legal norms, and to which extent they are influenced by the judge's personal ethical and ideological conceptions, is of course a very difficult challenge. This article has tried to show, however, that it is a task that can be successfully undertaken.

\section{REFERENCES}

\section{Literature}

Arstein-Kerslake A., Restoring Voice to People with Cognitive Disabilities: Realizing the Right to Equal Recognition before the Law, Cambridge 2017.

Bobbio N., Il positivismo giuridico, Torino 1979.

Cahill-O'Callaghan R., The influence of personal values on legal judgments, "Journal of Law and Society” 2013, Vol. 40(4), DOI: https://doi.org/10.1111/j.1467-6478.2013.00642.x.

Cuenca Gomez P., El derecho al voto de las personas con discapacidad intelectual y psicosocial. La adaptación de la legislación electoral española a la Convención Internacional de los Derechos de las Personas con Discapacidad, "Derechos y Libertades" 2018, No. 38.

Danielski D.J., Values as variables in Judicial Decision-Making: Notes toward a Theory, "Vanderbilt Law Review" 1965, Vol. 19.

Degener T., A human rights model of disability, [in:] Handbook of Disability Law and Human Rights, eds. P. Blanck, E. Flynn, London 2016.

Dziedziak W., Axiological Basis for the Application of Law - A Perspective of the Equitable Law, „Studia Iuridica Lublinensia” 2015, Vol. 24(2), DOI: https://doi.org/10.17951/sil.2015.24.2.49.

French S., Swain J., Changing relationships for promoting health, [in:] Tidy's Physiotherapy, ed. S. Porter, Edinburgh 2013.

Martínez-Pujalte A., Derechos fundamentales y discapacidad, Madrid 2015.

Martínez-Pujalte A., Legal Capacity and Supported Decision-Making: Lessons from Some Recent Legal Reforms, "Laws" 2019, Vol. 8(1), DOI: https://doi.org/10.3390/laws8010004.

Office of the United Nations High Commissioner for Human Rights, Awareness-raising under Article 8 of the Convention on the Rights of Persons with Disabilities (A/HRC/43/27), 17 December 2019, www.ohchr.org/Documents/Issues/Disability/Article8/A_HRC_43_27_AdvanceEditedVersion. docx [access: 20.01.2020].

Palacios A., El modelo social de discapacidad: orígenes, caracterización y plasmación en la Convención Internacional sobre los Derechos de las Personas con Discapacidad, Madrid 2008.

Palacios A., The social model in the International Convention on the Rights of Persons with Disabilities, "The Age of Human Rights Journal" 2015, Vol. 4.

Pritchett H., The Roosevelt Court, New York 1948.

Serna P., Filosofía del Derecho y paradigmas epistemológicos, México 2006.

18 See, e.g., P. Serna, Filosofía del Derecho y paradigmas epistemológicos, México 2006, especially pp. 105-126 (Chapter III "From positivism to hermeneutics"). 


\section{Legal acts}

Committee on the Rights of Persons with Disabilities, General Comment No. 1, Article 12: Equal recognition before the Law, 19 May 2014.

Convention on the Rights of Persons with Disabilities of 13 December 2006.

English Equality Act 2010.

\section{Case law}

Decision of the Spanish Constitutional Court of 28 November 2016.

\section{STRESZCZENIE}

Celem artykułu było określenie wpływu, jaki na decyzje sądowe ma podejście do niepełnosprawności wpisane w mentalność danej jednostki. Po przedstawieniu krótkiego wprowadzenia do różnych paradygmatów niepełnosprawności rozróżniono jej model medyczny i społeczny, zauważając, że ten ostatni został włączony do Konwencji o Prawach Osób Niepełnosprawnych. Analiza dwóch ostatnich orzeczeń hiszpańskiego Sądu Najwyższego ilustruje wpływ różnych modeli niepełnosprawności na orzeczenia sądowe. W podsumowaniu sformułowano wnioski, które mogą wyznaczyć kierunek przyszłych badań.

Słowa kluczowe: niepełnosprawność; Konwencja o Prawach Osób Niepełnosprawnych; sądowa interpretacja prawa 